\title{
ANTECIPAÇÃO DA TUTELA \\ JURISDICIONAL EM FACE \\ DO MANDADO DE \\ SEGURANÇA AMBIENTAL
}

Ruy de Jesus Marçal Carneiro ${ }^{1}$

SUMARIO: 1. Introduça - 2. O Mandado de Segurança: sua evoluçäo constitucional - 3. O Mandado de Segurança Individual e Coletivo: 3.1. - Lei n. ${ }^{\circ}$ 1.533, 31 de dezembro de 1951: algumas reflexóes - 3.2. - conceitos - 3.3. - juzo de admissibilidade - 3.4. - concessão de liminar - 3.5. - condição da ação - 4. A tutela antecipada: 4.1. - Carder individual: $\mathrm{Na}$ Lei ${ }^{\circ}{ }^{5}$ 5.869, 11.jan.73(Codigo de Processo Civil): arts. 273 e 461 - 4.2. - Carater coletivo: 4.2.1. Na Lei n. ${ }^{\circ}$ 7.34, 24.ju1.85(Acáo Civil Publica, art. $4^{\text {v}}$ ) - 4.2.2. Na Lei n. ${ }^{\circ} 8.078,11$. set.90(Codigo de Protecá e Defesa do Consumidor, art. 84) - 5. Direitos Difusos, Coletivos e Individual Honogêneo - 6. Do Meio Ambiente: 6.1. - Na Constituiço Federal/88, ants. 225; 23, incisos VI VII-6.2. - Na Lei . $^{\circ} 6.938,31$ ago.81 (Politica Nacional do Meio Ambiente). - 7. Consideraçoes Finats - 8. Bibliografia

RESUMO: O presente ensaio visa a tratar das variáveis que possam envolver o mandado de seguranç ambiental à luz da antecipação da tutela jurisdicional.

PALAVRAS-CHAVE: Sadia qualidade de vida - Tutela - Antecipação Mandado de segurança - Direito Ambiental

ABSTRACT: The aim of the present essay is to deal with the variables that might involve a writ os mandamus in the light of a juridical tutelage antecipation.

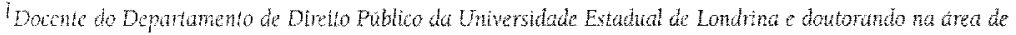

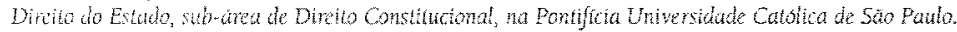




\section{INTRODUÇÃO}

$\boldsymbol{O}$ presente ensaio tem o objetivo de tratar de um assunto de profunda importância para os brasileiros $e$ os estrangeiros residentes no País, qual seja a da "Antecipação da tutela jurisdicional em face do mandado de seguranç ambiental", título, inclusive, deste trabalho.

Como se sabe, o mandado de segurança é remédio constitucional inserido no "Título II -Dos Direitos e Garantias Fundamentais-, Capítulo I Dos Direitos e Deveres Individuais e Coletivos-" da Carta Magna brasileira, que busca "proteger direito liquido e certo", anteriormente destinado a direitos de cunho individual. Hoje, entretanto, tal açăo nos precisos termos do art. $5^{\circ}, \mathrm{LXX}$, busca amparar o interesse coletivo.

Nesta linha de raciocínio, quando se fala da busca da tutela de direitos ambientais, tais tipicamente de conteúdo difuso, um "bem da vida" ressai com profunda relevância, merecedor, portanto, de que a máquina judiciária esteja à disposição da sociedade(e aqui está o interesse difuso) para protegélo. Fala-se, como se verá ao longo desta exposição, da dicção constitucional que visa a permitir a que todos possam ter direito ao meio ambiente ecologicamente equilibrado, bem de uso comum do povo e essencial à sadia qualidade de vida..., nos precisos termos do art. 225 da Lei Maior.

Desta forma, incursionar-se-a no âmbito da figura do mandado de segurança como o remédio pretendido para a outorga da tutela jurisdicional.

Em não podendo ser diferente, há de se verificar a evolução constitucional de tal remédio constitucional, a tempo em que se estudará o instituto da tutela antecipada nos meandros de diversos diplomas legais e nas suas mais variadas formas de concretização.

Por força disso, e como amparo para o ponto de vista aqui lembrado, năo se pode deixar de observar os ditames constitucionais que tratam do meio ambiente e a sua interação com o homem e com a sociedade, para que se compreenda o alcance tutelar do direito individual e coletivo em sede constitucional, bem assim a legislação infraconstitucional que daí delua.

Também, haverá de se perscrutar além do meio ambiente natural, aquele que é plasmado pelo homem, ou seja o meio ambiente chamado de artificial, sobretudo nas grandes cidades, já que se conta, hoje em dia, com 
as disposiçōes de todo um capítulo na Constituição Federal que visa a tratar da Política Urbana, nos precisos registros do seu art. 182, onde, igualmente, repousa um outro "bem da vida", ou seja a busca da garantia do bem-estar dos habitantes urbanos, para que estes circulem, morem, trabalhem $\mathrm{e}$ divirtam-se, usufruindo das plenas funções sociais das cidades.

E, portanto, o que se fará a seguir.

\section{O MANDADO DE SEGURANÇA: SUA EVOLUCÃO CONSTITUCIONAL}

O atual texto constitucional prescreve no Título II: Dos Direitos e Garantias Fundamentais, Capitulo I: Dos Direitos e Deveres Individuais e Coletivos, no seu art. $5^{\circ}$, LXIX:

conceder-se-á mandado de segurança para proteger direito liquido e certo, não amparado por habeas corpus ou habeas data, quando o responsável pela tlegalidade ou abuso de poder for autoridade publica ou agente de pessoa juridica no exercicio de atribuiçóes do poder público.

No inciso seguinte contempla uma evolução no âmbito dos direitos coletivos quando prescreve

o mandado de seguranca coletivo pode ser impetrado por:

a) partido politico com representação no Congresso Nacional;

b) organizacão sindical, entidade de classe ou associacao legalmente constituda e em funcionamento há pelo menos um ano, em defesa dos interesses de seus membros ou associados;

É, pois, o que se tem nos dias atuais. Entretanto, ao longo dos anos, houve uma evolução acentuada, tal como se transcreverá e comentar-se-á em seguida.

\section{Em 1934}

$\mathrm{Na}$ Constituição de 1934, quando veio a lume o instituto, aparecia assim, no seu art. 1.13, 33:

Dar-se-a mandado de segurança para defesa do direito, certo e incontestável, ameaçado ou violado por ato manifestamente inconstitucional ou ilegal de qualquer autoridade. O processo será o mesmo do habeas corpus, devendo ser 
sempre ouvida a pescoa de direito publico interessada. O mandado ná prejudica as acoes potionias competentes. - Grifou-se -

Cabe aqui, de pronto, uma observação acerca do dispositivo transcrito. Vê-se, à luz da preposição do, que antecede a locuçăo direito certo $c$ incontestavel, que ali fica firmemente registrado que se trata de um direito próprio, especifico para o caso em questão, e nào um direito amplo, geral, não-especifico. Era, portanto, a figura de um direito individual, já existente. Ou seja, só cabia a sua aplicaçao na hipótese da existência da violacio de um direito de conteúto concreto. Era assim que positivava o Codigo Crvil Brasileiro(Lei n. 3.071, de $1^{\circ}$ de janeiro de 1916), quando registrava, consoante o seu art. 75: A todo direito comesponde uma açăo que o assegura. Destarte, haver-se-ia de perguntar: como licaria, então, a perspceliva de uma improcedencia à aça competente do mandado de seguranca fí que se tratava da aefesa DO direito..? Assim, como compatibilizar o comando legal que diccionava: Dar-se-á nandado de seguranç para defesa do direito, certo e incontestável. Se o direito é certo e incontestavel, como conviver, entäo, com a perspectiva de uma improcedencia. No ponto, lica o registro.

\section{Ean 1937}

No "Estado Novo" de Getulio Vargas, o instituto do mandado de seguranca foi extirpado do texto constitucional de 1937. Năo poderia se: diferente csta intença do governante da época, face ao regime de arbítro em que vivia o Pas. Somente coma a legislaça infraconstitucional, comporlicada na Lei n. 191, de 16 de janeiro de 1936. Manteve-se, cntictanto, por estranho que parecer possa, o "habeas corpus"(art. 122/16), genese do "writ" constitucional.

\section{Em 1946}

Ao seut tumo, a Constituiçáo de 1946, em razão dos ventos kemocráticos que soptavam no Brasil, no apos-guerra, esta Carta prescrevia no seu art. 141, \& 24, que

Para proteger diribo liquido cento näo amporado por habeas corpus, concederse-a mandado de seguranca, seja qual for a auloridade responsavel pela ilegalidude mu abiso de poder.

Como se depreende, a simples leitura do texto constitucional, a 
expressão incontestável foi dele escoimada para dar: lugar a direito liquido e certo, que é o que se tem até hoje.

Esta nova locução, direito liquido e certo, inclusive nos dias que correm, tem dado azo a interpretaçóes diversas, que merecem ser anotadas para efeito de registro e de reflexão, como se verá no momento apropriado. Dai, vigiu tal dispositivo até a proximidade da década dos anos setenta.

\section{Em 1967}

Com a promulgação de nova Constituição Federal, foi trazida à luz o art. $150, \& 21$, quando registros de importância quedaram-se concretizados.

Neste caminho, o texto passou a trazer uma inovação, delimitando o campo de aplicabilidade do remédio constitucional, quando registrado estava que

Conceder-se-a mandado de seguranç, para proteger direito INDIVIDUAL liquido e certo náo amparado por habeas corpus, seja qual for a autoridade responsavel pela ilegalidade ou abuso de poder. - Destacou-se -

No destaque acima, o que se verifica é que o texto explicita que o alcance terá conteúdo INDNVDUAL, muito embora aquela época nem se Calasse nos direitos coletivos ou difusos, tão em voga nos dias de hoje. Entretanto, se a medida visava a preservaça de direito líquido e certo, como era, anteriomente, prescrito, agora o exercicio estava restrito a direito individual, por força da norma constitucional.

\section{$\operatorname{Em} 1969$}

Conceder-se-a mandado de segurança para proteger diseito laquido e cento näo amparado por habeas corpus, seja qual for a autoridade responsavel pela llegalidade ou abuso de poder.

De imediato, à simples leitura do novo texto constitucional, verificase que a expressão para proteger direito individual liquido e ccrto existente na Carta anterior, dava lugar a um novo tratamento, qual seja a proteção de direito liquido e certo de maneira ampla, permitindo-se, então, "a tutela dos direitos que ultrapassavam a órbita do individuo", espraiando-se, pois, para os metaindividuais, difusos, coletivos etc; tal como preleciona Celso 
Antonio Pacheco Fiorillo et alli2 : "...tratava-se de uma brecha que permitia a tutela dos referidos direitos metaindividuais."

Esta, portanto, a modificação de importância trazida à luz pelo novo texto constitucional. Notava-se, por consequência, a ampliação de tal dispositivo em relação ao que vigia anteriormente a ele. Pode-se dizer, inclusive, que a relerida dicção ampliava o campo de atuação do citado remédio previsto em nossa Carta Magna.

\section{Em 1988}

Art. $5^{\circ}$ Todos são iguais perante a lei, sem distinção de qualquer natureza, garantindo-se aos brasileiros $e$ aos estrangeiros residentes no Pais, a inviolabilidade do direito à vida, à liberdade, à igualdade, à segurança e à propriedade, nos termos seguintes:

Omissis

LXIX - conceder-se-â mandado de segurança para proteger direito liquido e certo, näo amparado por habeas corpus ou habeas data, quando o responsável pela ilegalidade ou abuso de poder for autoridade publica ou agente de pessoa juridica no exercício e atribuiçoes do Poder Público;

LXX - o mandado de segurança coletivo pode ser impetrado por a) partido politico com representaça no Congresso Nacional; b) organização sindical, entidade de classe ou associaçäo legalmente constituida e em funcionamento há pelo menos um ano, em defesa dos interesses de seus membros ou associados.

Na prescrição desta Constituição, como se vé, o instituto do mandado de segurança passa a ter um alcance maior, pois se a um turno permite continuar a impetração com vístas ao comentado direito individual, por outro articula este recurso à observância da tutela do chamado interesse(direito) coletivo, quando, no inciso LXX, alarga a proteção ao chamado direito líquido e certo extensivo a: a) partido politico com representaçăo no Congresso Nacional; b) organizaçāo sindical, entidade de classe ou associaça legalmente constituida e em funcionamento há pelo menos um ano, em defesa dos interesses de seus membros ou associados.

2 C.F. "Direino Processual Ambientai Btaslero", Del Rey, Belo Honizonte, 1996, p. 192 
Nesta linha da inovação constitucional, leia-se o ensinamento de Celso Ribeiro Bastos:

O mundo moderno suscita diversas situaçoes em que a lesão a direitos se dá de forma massificada e padronizada. Não se vê por que não resolver todas essas situaçoes numa unica açäo. Dai a razäo pela qual a criação de um mandado de segurança coletivo afigura-se-nos oportuna e com o tempo temos para nós venha a se mostrar até muito útil. ${ }^{3}$

Nestes rápidos registros a evolução, então, do tema mandado de segurança no corpo de nossas Cartas Constitucionais.

De ora em diante, ver-se-ão alguns outros aspectos que envolvem a citada aça constitucional, como a forma de sua operacionalização por intermédio da legislação infraconstitucional(Lei n. ${ }^{\circ} 1.533$, de 31 de dezembro de 1951, conceitos, juizo de admissibilidade etc., anteriormente ao desenvolvimento do tema desta monografia.

\section{O MANDADO DE SEGURANCA INDIVIDUAL E COLETIVO}

\section{1. - Lei $n .{ }^{\circ} 1.533,31$ de dezembro de 1951: algumas reflexões:}

A epigrafada é a lei disciplinadora do exercício do mandamento constitucional tradicional(individual). Foi editada à luz da Constituição Federal de 1946(ant. 141, \& 24); recepcionada4 por três Constituições: 1967 (art. 150, \&21); 1969 - EC n. ${ }^{\circ} 1 / 69$-(art. 153, \& 21); 1988(art. 5\%, LXIX e $\mathrm{LXX}$. A sua primeira edição tinha o condão de alterar as disposições do Código de Processo Civil, relativas ao mandado de segurança. Embora esta Lei traga importantes passos para a impetração do mandado de segurança no que toca a sua processualística, alguns pontos merecem ser analisados, embora não seja o conteúdo do presente trabalho, mas que podem ficar gravados como uma contribuição para a sua díscussão.

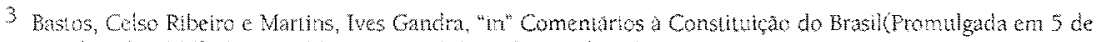

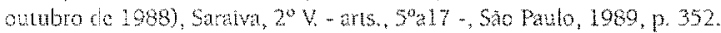

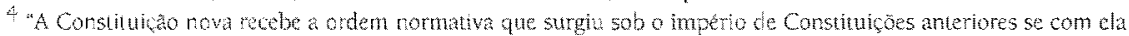

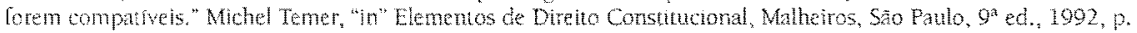
36. 
Um deles diz respeito ao art. 18, que discipina, desde 1951, o prazo para sua propositura, de forma que:

O direito de requerer mandado de seguranca extingüir-se-á decorridos cento e vinte e dias contados da ciencia, pelo interessado, do ato impugnado.

Neste ponto, ê importante que se transcreva uma lúcida conclusāo em artigo 5 la lava do Professor Geraldo Ataliba, que, ao longo do mesmo, mostrama a inconstitucionalidade do prazo decadencial de cento e vinte e chas para a impetração deste remédio constitucional.

Num passo, transcrevia o ministro Carlos Velloso, quando este proferia o seguinte pronunciamento em "MS 21.356-6", que tramitava no Supremo Tribunal Federal:

Voto - O Sr. Ministro Carlos Velloso:-Senhor Presidente, apenas duas palauras, para uma dedaraço de principio. Tenho o prazo do art. 18 da Lei 1.533 , de 1951 - a dizer que o direito de requerer o mondado de seguranga se extinguira deconidos conto vinte e dias, contados da ciencia, pelo interessado, do ato impugnado - como atentutório à naturza da aça do mandado de seguranca. É que a Constituica, que estabetece os requisilos da aça, não prevè nenhum prazo para seu excricio. Dir-se-a que an Congresso é permitido, mediante leis processudis, stabelecer prazos de decadencia e prazos de prescrição. Em linha de principio, concondo com a objeção. Tenho minhas düvidas, entretanto, quando se trata de uma aça constitucional, como $\dot{e}$ o caso do mandado de seguranç, remidio constitucional, garantia constitucional, equando o prazo estabelecido, que ¿ de decadencia, ná se assenta numa razáo cientifica, conforme lombre em Whatho doutrinario que escrevi "Conceito de Direito Liquido Certo", in Curso de Mondalo de Seguranca, Ed. Rev dos Tribunais, 1986, pags. 85 e segs.).

Noutro passo, firme em Seabra Fagundes, trazia o ensinamento deste, quanto alo assunto que cuidava:

O Ministro Sedbra Fagundes que, no seu precioso Do Controle dos Atos Administrativos pelo Poder Judiciario, sustentou a legitimidade do referido prazo,

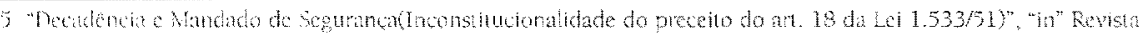

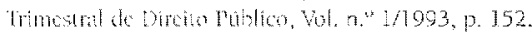


Ia retificon a sua opinià e sustenta, agora, ser ilegitimo o prazo de caducidade do mandado ue segurança. Isto pude verificar dos debates de que S. Exa participou, no Instituto dos Advogados, após palestra que ali proferi, em 1984, a respeito do tema. (...).

Por lim, consciente da inconstitucionalidade do prazo decadencial em mandado de seguranca, consoante o seu escrito, registrava o seu pensamento, e mais que isso, o seu apelo dizendo que

Cabe ans advogados pleitear, instar para que o Judiciario acolha esta liça e de a Coneliluiçio a dignidade propria de Lei Magna, incontrastavel e Suprema.

Como dizia o saudoso e eminente Victor Nunes Leal, lei não cerceia Consitucáco.

Elinalizava com a enfase dos estudiosos:

Mandado de Seguranca desconhece prazo constitucional (o unico plano onde pode ser substancidmente regulado) para a sua propositura.

Questäo, pois, a ser cuidada pelos pesquisadores.

Além disto, outra questão merece ser tratada com o cuidado que ela merece. Trata-se da falta de uma mais cuidada e moderna regulamentacão para o exercicio deste remédio constitucional, sobretudo agora que se tem uma amplitude maior na sua aplicaçäo.

A legislacão infraconstitucional que trata da processualística sobre o mandado de segurança, como se sabe, tem mais de quatro décadas. Inclusive, veio para ahterar disposiçoes do Codigo de Processo Civil de 1939, carecendo de novas tintas para que se ajuste is novas dicçoes do atual texto constitucional.

Uma delas, registrada anteriomente, quanto ao prazo de sua impetraçá, esta claro que não mereceu da nova Carta Magna a necessária recepcão, tendo en conta a ampliação dos direitos individuais e coletivos que esta outorgou à sociedade brasileira.

Nesta linha de raciocinio, um outro ponto merece uma necessária rellexão. Trata-se das medidas liminares que se eternizam no Judiciario. A Lei n." 4.348 , de 26 de junho de 1964 , no seu art. $1 \%$, b. deixou registrado que a medida liminar somente terá eficacia pelo prazo de (90) noventa dias a 
contar da data da respectiva concessäo, prorrogável por (30) trinta dias quando provadamente o acúmulo de processos pendentes de julgamento justificar a prorrogaçäo. Entretanto, não há no referido texto qualquer sanção à autoridade judiciária que deixe de atender tal prescrição, razão por que existem casos em que tal medida preliminar estende-se por meses a fio sem nenhuma solução.

Como se vê, por força da nova Constituição, seria de bom alvitre que uma nova regulamentação sobre a impetração do mandado de segurança pudesse ser criada, sobretudo quando se tem legislado constitucionalmente sobre a figura do mandado de segurança coletivo, adequando-se, pois, a legislação infraconstitucional à vontade da Carta Maior nestes novos tempos em que se vive.

Fica, pois, a lembrança

\subsection{Conceitos:}

Para que se conceitue este remédio constitucional, buscar-se-ão os ensinamentos de alguns dos importantes juristas pátrios, objetivando, inclusive, e desde logo, traçar a linha conceitual tanto do mandado de segurança individual, como a nóvel figura do mandado de segurança coletivo, novidade trazida à luz pela vigente Constituição Federal.

Por primeiro, registre-se o que doutrina Hely Lopes Meirelles, no seu Mandado de Segurança, Açāo Popular, Ação Civil Pública, Mandado de Injunção e 'Habeas-Data', RT, S. Paulo, 1989, p. 3:

Mandado de Seguranca Individuat: "é o meio constitucional posto à disposição de toda pessoa fisica ou juridica, órgáo com capacidade processual, ou universalidade reconhecida por lei, para a proteção de direito individual ou coletivo, liquido e certo, não amparado por habeas corpus, lesado ou ameaçado de lesão, por ato de autoridade, seja de que categoria for e sejam quais forem as funçoes que exerça" (CF/88, art. 5\%, LXIX e LXX - Lein. ${ }^{\circ} 1.533 / 51$, art. 1)

Ovidio A. Baptista da Silva, por seu turno, em Curso de Processo Civil, v. II, Sérgio Fabris Editores, p. 312, e já tratando do mandado de segurança coletivo, diz: 
Mandado de Seguranca Coletivo. "É necessário determinar se o Mandado de Seguranca Coletivo, como o comum, protege exclusivamente o 'direito liquido de certo', correspondente a uma determinada comunidade de impetrantes, representados pela entidade legitimada para a açäo; ou, se além dos direitos individuais liquidos e certos', poderão igualmente ser amparados por ele os denominados 'interesses difusos'

Depois averba:

...ser o Mandado de segurança coletivo nada mais nada menos do que o mesmo Mandado de Seguranç, inscrito no art. 5\%, LXIX da Constituição Federal, a que apenas se outorgou legitimação especial às entidades representativas de grupos sociais interessados na defesa do mesmo direito subjetivo - pertencente aos respectivos grupos sociais - quando ameaçados ou violados por ato ilegal da autoridade.

\section{Calmon dos Passos, na sua obra Mandado de Segurança Coletivo,} Mandado de Injunçäo, 'Habeas Data', 1989, p. 13, registra, também tratando do remédio constitucional a nível coletivo, comenta:

A Constituição permite distinguir três situações que não cabe serem confundidas:

a) a impetraçäo, pela entidade, do mandado de segurança em seu próprio favor, na defesa do direito publico subjetivo de que seja titular;

b) a impetraçăo, pela entidade, de mandado de seguranç em favor de associados. porque expressamente autorizada por elas na espécte; aqui pode a entidade agir sem qualquer limitação ou vinculo, porque o objetivo do inciso XXI do art. $5^{\circ}$ da CFo foi proporcionar o apoio(serviço) da entidade ao associado, nos limites em que o associado julga conveniente esse apoio;

c) a impetração, pela entidade, de mandado de segurança coletivo em favor de seus membros ou associados como substituto processual e independente de autorizacão deles, por estarem em jogo direitos(individuais) de associados seus, direitos esses que guardan certo vinculo com os fins mesmos da entidade(interesse qualificador do vinculo associativo).

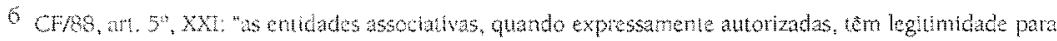
repesentur seus hlotos judicial ou exiandiciatmente." 
Assim, obtidas tais conceituações e já no âmbito do Mandado de Segurança Coletivo, pode-se perguntar:

$\left.1^{\circ}\right)$ ele se presta para proteger de forma global direitos individuais, os quais poderiam ser impetrados em ações individuais, ou busca defender direitos coletivos?

$2^{\circ}$ ) ou serve para proteção de defesa de interesses coletivos, senso lato?

Respondendo: na primeira situação não se trata de instituto novo, mas sim extensão aperfeiçoada do primeiro; abarca-se num mesmo processo direitos subjetivos individuais, evita-se, pois, a construção de litisconsórcio; na segunda posição, impera um instituto novo, pois busca-se proteger direitos coletivos.

A questão: presta-se o Mandado de Segurança para proteger os direitos subjetivos individuais das pessoas que eventualmente possam estar enquadradas no grupo a que o interesse difuso, como por exemplo, dispositivos concernentes ao meio ambiente, devam ser resguardados?

Conforme Lúcia Valle Figueiredo, "in" Perlil do Mandado de Segurança Coletivo, RT, 1989, p. 15, desde que passiveis de serem provados de plano, podem ser garantidos pelo mandado de segurança coletivo. Logo, a questão é de prova, exigência em postulação de qualquer Mandado de Segurança, por ser de sua essência quanto ao direito liquido e certo. Todavia, como esta é a perquirição do presente trabalho dela tratar-se-á à frente com mais detença.

\section{3. - Juizo de Admissibilidade:}

No tocante ao chamado juizo de admissibilidade para a postulaçào através de mandado de segurança, algumas características devem ser cuidados, sob pena de não fazendo, ter-se por terra a perspectiva da impetraçăo.

Pode-se, portanto, dividir os pressupostos processuais em duas áreas.

A primeira, que se pode chamar de pressupostos processuais positivos de validade, deve respeitar que se tenha uma petiço inicial regular e apta; 
que haja competência do Juizo no âmbito do qual se postulará a ação constitucional; que este Juizo seja resguardado no que toca à "ausência de impedimentos" e que se tenha, por parte do autor, a chamada capacidade processual. Por outro pólo, já agora no interior dos pressupostos processuais negativos de validade, que não tenha ocorrido a "coisa julgada" e que não haja litispendéncia.

Destarte, para que uma relaçäo processual tenha existência, no que toca ao mandado de segurança, seja individual ou coletivo, será necessário, pois: a) uma petição que contenha um pedido; b) que tal pedido seja dirigido a um órgão jurisdicional; c) que ocorra a notificação da autoridade coatora; d) que haja representação por um advogado(capacidade postulatória). Presentes as pressupostos processuais positivos, ausentes os negativos, existente e válida será a relação processual no mandado de segurança individual ou coletivo.

\section{4. - Concessão de Liminar:}

Na impetração de um mandado de segurança, via de regra, o autor ao submetêta ao Judiciário o faz buscando, desde logo, a concessão de uma tutela liminar, submetendo-se esta aos pressupostos do "Tumus boni iuris" e do "periculum in mora", condiçōes básicas para a sustentação do pedido.

Ou no escólio de Hely Lopes Meirelles:

'A medida liminar é provimento cautelar admitida pela própria le de mandado de segurança,' quando sejam relevantes os fundamentos da impetração e do ato impugnado puder resultar a ineficácia da ordem judicial, se concedida a final art. $\left.7^{\circ}, 11\right)^{7}$.

Um pedido de liminar, por isto, deve contemplar, ainda, certas características, como, por exemplo: urgência, cognição sumaria, provisoliedade e revogabilidade. As duas últimas, pode-se dizer, é espada que a qualquer momento pode pender sobre a cabeça do impetrante, posto que, repita-se, a liminar é sempre provisória e revogável tendo em conta as informaçoes que venham a ser prestadas pela autoridade coatora.

$70 p, a, n, 50$ 
Celso Antonio Pacheco Fiorillo et allis, dizem que devem ser diferenciadas a cognição da concessão das medidas liminares com a da cognição da própria ação e, no que aqui interessa, registram os autores que: ...temos que em sede de mandado de segurança coletivo ambiental, quando se alude à expressāo "proteção de direito liquido e certo", não se está, obviamente, aludindo à existência, de plano, de direito liquido e certo, mas, sim, fazendo mençăo à existência de um momento sumário de cogniçäo do juiz, qual seja, o da possibilidade de concessão de liminar.

Por outro norte, cabe registrar aqui mais uma preocupação quando se fala da outorga de liminares em mandado de segurança. E ela refere-se ao que determina o art. $1^{\circ}$, "b", da Lei Federal n. 4.348 , de 26 de junho de 1964, que, textualmente prescreve:

Art. 10. Nos processos de mandado de segurança seräo observadas as seguintes nomas:

(..)

b) a medida liminar somente terá eficácia pelo prazo de (90) noventa dias a contar da data da respectiva concessäo, prorrogável por (30) dias quando provadamente(sic) o acumulo de processos pendentes de julgamento justificar a prorrogacăo.

Nota-se, desde logo, que uma liminar, quando muito, deveria vigir täo só pelo prazo de (90) noventa dias a contar da data da respectiva concessão, prorrogável, no entanto, por (30) dias quando provadamente o acúmulo de processos pendentes de julgamento justificar a prorrogaçäo.

Todavia, não é isto o que ocorre na prática. Há casos, e o Estado do Paraná, justamente em matéria ambiental, dá conta de liminar que avança, e muito, ao longo do tempo, como é o caso do litígio conhecido como a "Estrada do Colono", região localizada no sudoeste desta unidade da federação, cuja medida acautelatória faz-se de pé por quase uma década(!!!). Evidentemente que isto atenta contra o ordenamento jurídico, e pior, contra a própria segurança jurídica. E, na maior parte das vezes, tal fato é difícil de

Bop.cin., p. 209 
ser atribuido ao provadamente (...) acumulo de processos pendentes de julgamento justificar a prorrogaçào, como registra a lei já nominada.

Em todo o caso isto acontecée quantos outros não ocorrem ao longo do Pais?), há de se presumir que a Justiça tenha melos para coibir tais práticas ilegais e danosas a todos.

Entretanto, fica o registro e avance-se para o desenvolvimento deste trabalho.

\section{5. - Condição da Ação:}

De forma sintética, a seguir, serão traçados alguns registros acerca da chamada condição da ação, que tanto vale para a açäo constitucional do mandado de segurança quanto para as açoes de qualquer tipo que estão disciplinadas pelo Código de Processo Civil.

Assim:

1) legitimidade de parte("ad causam"): plausibilidade da afirmação de titularidade e legitimidade para agir, feita na inicial;

2) interesse processual: necessidade e utilidade do provimento postulado, que deve ser adequado;

3) possibilidade juridica do pedido: admissão em tese, pelo ordenamento jurídico, do que vem consubstanciado no pedido.

Ou, noutro esquema'

A. MATERIAL.

A.1. Titularidade:

Polo ativo ou passivo da relação juridica;

\section{A.2. Legitimidade:}

Poder de exercer, defender o direito(em juizo, ou no dia a dia), e sofrer as consequências desse mesmo exercício;

\section{A.3. Interesse:}

Vantagens e desvantagens que o direito pode trazer ao seu titular;

9 Conforme BFINETh, Luiz Femando, Mandado de Segurança Coletivo. Tese de Doutorado, defendida juno a Ponthcla Universidade Catblua de Săo Panlo, 1997 


\section{A.4. Capacidade:}

Aptidão para a efetiva aquisição e exercício pessoal dos direitos;

\section{A.5. Objeto:}

Física e juridicamente possível;

A.6. Forma adequada:

Conjunto de requisitos materiais ou extrínsecos que devem estar presentes para que um ato possa existir ou ter eficácia;

\section{B. PROCESSUAL}

B.1. Legitimidade "ad causam":

Plausibilidade da afirmação da titularidade e legitimidade para agir registrada na inicial;

B.2. Legitimidade processual:

Poder de defender o direito afirmado (concreto) em juizo;

\section{B.3. Capacidade Processual:}

Aptidão genérica para ser parte e estar em juízo;

B.4. Interesse Processual:

Necessidade e utilidade do provimento, que deve ser adequado;

B.5. Possibilidade Juridica:

Admissão, em tese, pelo ordenamento do pedido;

B.6. Adequação:

A tutela deve servir para o fim colimado, que deve ser atingido pelo procedimento adequado.

Comentados alguns aspectos do mandado de segurança, tal como anteriormente restou gravado, e tendo em conta que o objetivo deste trabalho é tratar também da figura da antecipação da tutela jurisdicional quando da impetração daquele, é mister que à frente trate-se dela, que é o que se fará no próximo caminho.

\section{A TUTELA ANTECIPADA}

\section{1. - Caráter Individual}

NA Lei n. ${ }^{\circ} 5.869,11 . j a n .73$ (Cödigo de Processo Civil), arts. 273 e 461; 


\section{2. - Caráter coletivo}

Na Lei n. ${ }^{\circ} 7.347,24$.jul.85(Ação Civil. Pública): art. 4\%;

Na Lei n. ${ }^{\circ}$ 8.078, 11.set.90(Código de Proteção e Defesa do Consumidor): art. 84

A chamada tutela antecipada, à luz da legislação pátria apresenta-se com meios que visam tanto atender ao aspecto individual, como coletivo das demandas. Assim, demonstrar-se-á a sua existência nas modificaçoes trazidas pela Lei Federal n. ${ }^{\circ} 8.952$, de 13 de dezembro de 1994, ao Código de Processo Civil(Lei Federal n 5.869 , de 1.1 de janeiro de 1973), nos seus arts. 273 e 461 , estes, pois, alinhados com o aspecto individual; enquanto que os que se seguem tratam dos litígios coletivos, quais sejam: Lei Federal n. ${ }^{\circ}$ 7.347 , de 24 de julho de 1985 (Açäo Civil Pública), no seu art. 4\%; Lei Federal n." 8.078, de 11 de setembro de 1990(Código de Proteção e Defesa do Consumidor), no seu art. 84.

Como se pode depreender säo instrumentos que prescrevem os meios para a obtençăo da chamada antecipação da tutela jurisdicional, razão por que, para que se os gravem, de forma detida, são os mesmos transcritos a seguir:

\section{Caráter individual:}

Na Lei ${ }^{\circ} 5.869,11$ jan.73(Código de Processo Civil):

alts. 273 e 461 :

Art. 273. O juiz podera, a requermento da parte, antecipar, total ou parcialmente, os cfeitos da tutela pretendida no pedido inicial, desde que, existindo prova incquivoca, se convença da verossimithança da alegaçăo e:

1 - haja Jundado receio de dano imparavel ou de diffeil reparação; on

If - fique curacterizado o abuso de direito de defesa ou o

manifesto proposito protelatóno do réu.

$\$ 1 \%$ Na decisão que antecipar a tutela, o juiz indicará, de modo claro e preciso, as razós do sea convencimento.

$\$ 2^{\circ}$ Nao se concederá a antecipacá da tutela quando houver perigo de irreversibilidade do provimento antecipado. 
\& $3^{\circ}$ A execuça da tutela antecipada observara, no que couber, o disposto nos incisos II $e$ III do art. 58810.

$\S 4^{\circ}$ A tutela antecipada poderá ser revogada ou modificada a qualquer tempo, em decisão fundamentada.

$\$ 5^{\circ}$ Concedida ou não a antecipaçăo da tutela, prosseguirả o processo até seu julgamento final.

Art. 461. Na ação que tenha por objeto o cumprimento de obrigaçäo de fazer ou não fazer, o juiz concederá a tutela especifica da obrigaçăo ou, se procedente o pedido, determinará providencias que assegurem o resultado prático equivalente do do adimplemento.

$\S 1^{\circ}$ A obrigaça somente se converterá em perdase danos se o autor o requerer ou se impossivel a tutela especifica ou a obienção do resultado prático correspondente.

$\S 2^{\circ}$ A indenização por perdas e danos dar-se-á sem prejuizo da multa (art. 287).

$\$ 3^{\circ}$ Sendo relevante o fundamento da demanda e havendo justificado receio de ineficácia do provimento final, é licito do juiz conceder a tutela liminamente ou. mediante justificaçăo prévia, citado o réu. A medida liminar poderá ser revogada ou modificada, a qualquer tempo, $\mathrm{em}$ decisto fundamentada.

$\S 4^{\circ}$ O juiz poderá, na hipótese do parágrafo anterior ou na sentença, impor multa diaria ao réu, independentemente de pedido do autor, se for suficiente ou compativel com a obrigaça, fixando the prazo razoavel para o cumprimento do precetto.

$\S 5^{\circ}$ Para a efetivação da tutela especifica ou para a obtença do resultado prático equivalente, poderá o juiz, de oficio ou a requerimento, determinar as medidas necessárias, tais como a busca e apreensão, remoça de pessoas e coisas, desfazimento de obras, impedimento de atividade nociva, alem de requisição de força policial.

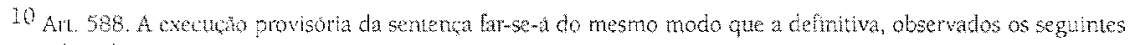
princlpios:

(..)

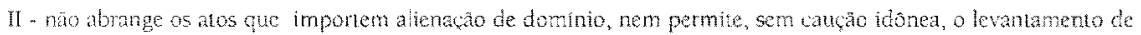
demsito em dinherr.

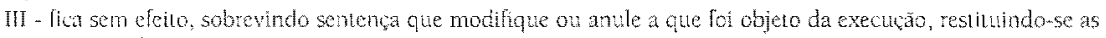
colsas me cstado anteriot.

Paragralo untco. No uno do n. In, deste artigo, se a sentenca provisoriamente execuada for modificada ou anulada aperas om parte somente nesea parte lichá sem eleito a execucâo. 
O que é importante de ser salientado é que o atual Código de Processo Civil, de conteúdo individual, no afã de melhor tutelar os interesses levados a Juizo, trouxe as modificaçoes que se concretizaram com a nova diç̧ão dos arts. 273 e 461. Tudo, como preleciona Cândido Rangel Dinamarcoll, dizendo que

O novo art. 273 do Código de Processo Civil, ao instituir de modo explíito e generalizado a antecipacão dos efeitos da tutela pretendida. veio com o objetivo de ser uma arma poderosissima contra os males corrosivos do tempo no processo. Inserindo-o no Livro I do Codigo de Processo Civil, que tem por objeto o processo de conhecimento, o legislador tomou posiçäo quanto a uma questäo conceitual que ja foi muito importante, que é da possivel natureza cautelar da antecipaça da propria tutela pretendida no processo de conhecimento. (grifos do autor citado).

Em seguida, este mesmo autor registra que esta antecipação de tutela é própria, agora, do processo de conhecimento, pela sua inserção na topografia do Código a que pertence este procedimento.

Assim, em outras palavras, somente neste procedimento é que se pode invocá-la; no processo cautelar, com todo o seu procedimento próprio, remanesce, ainda, os efeitos das medidas de cautela ali estabelecidas.

O que de novo acontece é que a modificaçäo ao direito processual veio oferecer rapidamente a quem veio ao processo pedir determinada soluçäo para a situaça que descreve, precisamente aquela soluça que de veio ao processo pediriz.

Outro ponto importante na nova disposição do Código de Processo Civil, por intermédio do já falado art. 273, é o condicionamento para a outorga da tutela, desde que existam duas liguras de realce para a sua concretização. A primeira, que o juiz se convença da verossimilhança da alegação e (caput do artigo), que haja fundado receio de dano irreparável ou de dificil reparaçăo(inciso I do artigo); ou fique caracterizado o abuso de direito de defesa ou o manifesto propósito protelatório do réu(inciso II do artigo em comento).

\footnotetext{
11 A Retoma do Codigo de Precesso Givil, Whatheros, 3. ed. S. Bulo, 1996 p. 140. 120 p. an. p. 141
} 
Quanto à verossimilhança, há de ser dito que isto se caracteriza na razăo direta de que o julgador deve ter no seu espírito tanta certeza quanta a que existe por parte daquele que a pede, ou, noutras palavras, que existe ampla possibilidade de que esta probabilidade ${ }^{13}$ ocorra. Todavia, mesmo estando convicto o juiz de entender de antecipar a tutela pretendida, não se perca de vista que a mesma tem caráter de provisoriedade, podendo, a final, ser revogada.

Noutro pólo, ainda no corpo do mesmo Código de Processo Civil, aparece a modificação no art. 461, trazido pela Lei n. ${ }^{\circ} 8.952$, de 13 de dezembro de 1994, que reproduz o que determina o art. 84 do Código de Proteção e Delesa do Consumidor, de maneira bastante fiel, disciplinando de Corma larga a tutela das obrigaçōes. Destarte, esta nova redação tem

dimensab suficiente para abranger bolas as obrigaçoses especficas ocomentes na vida das pessoas, seja as de origem legal, seja contratual14,

de lal forma que o que era reinante no âmbito das relaçôes de consumo aharca, agora, a plenitude do acesso à justiça.

Desta maneira, são estas duas figuras que contemplam os interesses individuais insertas no Código de Processo Civil.

Deste, para a Lei n. ${ }^{\circ} 7.347,24 . j u l .85$ (Ação Civil Pública), no seu ant. $4^{\circ}$, e para a Lei n. ${ }^{\circ}$.078, 11.set.90(Codigo de Proteção e Defesa do Consumidor), no seu art. 84, onde ambas cuidam dos interesses coletivos, na sua verdadeira acepção, é que se encaminhará a seguir.

\section{Caráter coletivo:}

\section{Na Lei n." 7.347. 24.jul.85(Acão Civil Pública): art. $4^{\circ}$ :}

Art. 4\% Podera ser ajuizada aço cautelar para fins desta lei, objetivando, inclusive, evita o dano ao meio ambiente, ao consumidor, aos bens e direitos de valor anistico, estético, historico, turistico e paisagistico.

Por primeiro é de se ressaltar que a aça civil pública encontra a sua genese na Constituição Federal, no seu art. 129, quando prescreve as funçôes

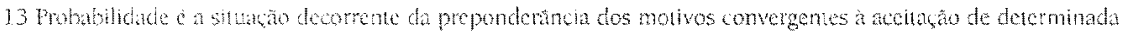

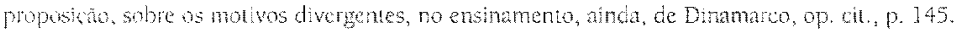

$1+$ Dinamitro, op tit., p. 151 .
} 
institucionais do Ministério Público, que são, dentre outras:

$1-(.$.$) ;$

$11-(\ldots)$;

III - promover o inquérito civil e a ação civil publica, para a proteção do patrimônio publico e social, do meio ambiente e de outros interesses difusos e coletivos; - destacou-se;

muito embora a lei que a discipline date de 24 de julho de 1985 , tendo sido, entretanto, perfeitamente recepcionada, quanto a esta parte, pelo atual texto constitucional, sem nenhum embargo, sendo de ser salientado que o Ministério Público é aquele que detém a legitimidade ativa para os aspectos processuais.

No que aqui interessa, verifica-se que o art. $4^{\circ}$ da comentada lei, já, muito antes da inovação trazida pelo Codigo de Processo Civil, quanto à antecipação da tutela jurisdicional, registrava que

Poderá ser ajuizada ação cautelar para fins desta lei, objetivando, inclusive, evitar o dano ao meio ambiente, ao consumidor, aos bens e direitos de valor artístico, estético, hislórico, turistico e paisagístico. - Destacou-se-.

Nesta senda, ressalte-se o que afimava Hely Lopes Meirelles:5 quanto às novidades trazidas por esta lei:

A açáo civil publica, disciplinada pela Lei 7.347, de 24.7.1985, é o instrumento processuat adequado para reprimir ou impedir danos do meio ambiente(..). Näo se presta a amparar direitos individuais, nem se destina à reparação de prejuzos causados a particulares pela conduta, comissiva ou omissiva, do réu.

Mcio ambiente, para fins desta ação, é o conjunto de elementos da Naturezaterra, agua, ar. flora e fauna - ou criaçoes humanas essenciais à vida de todos os seres e ao bem-estar do homem na comunidade. A Constituição de 1988 dedicou um Capitulo (art. 225 e $\$ \xi$ ) ao meio ambiente, onde estabelece os instrumentos para sua proteçáo. Grifos do autor citado.

Digno de registro quanto à aplicação desta lei é o comentánio feito por

150 p. th. p. 110 
Celso Antonio Pacheco Fiorillo et allit, dizendo que com o aparecimento do Código de Proteção e Delesa do Consumidor - Lei Federal n ${ }^{\circ} 8.078$, de 11 de setembro de 1990 - ocorreu uma nova fase para esta lei que cuida da ação civil pública, pois

(..) atraves da perfeita interação entre os dois diplomas, aumentou profundamente o alcance da Lei $n .7 .347 / 85$, o seu corpo legal e deu novo impulso ao uso da referidalei.

Exemplos marcantes dessa interação foram os arts. 90, 110 e 117 do CDC, do seu alcance (talvez a mudança mais importante que fol a inclusäo do inciso IV do art. $1^{\circ}$ da LACP), que foi a possibilidade de defesa de outros interesses difusos, e da sua integraçao dada pelos arts. $5^{\circ}, \S 3^{\circ}, 4^{\circ}, 15,18$, dentre outros.

Firma-se, portanto, de forma inequívoca a compreensão de que o supra citado art. $4^{\circ}$ da Lei n $.^{\circ} 7,347 / 85$, por força do seu art. $4^{\circ}$, traz à lume a possibilidade de uma antecipação de tutela, para que se evite o dano ao meio ambiente, dentre outros, além de que o instrumento legal mencionado, com a legitimaçăo do Ministério Público tem um alcance para a óbita dos interesses difusos e coletivos.

Para os objetivos desse trabalho é importante que se dissertem as hipóteses da abrangência da tutela antecipatóna, sem o que o meio ambiente, direito de todos, estaria desamparado. Neste compasso, caminharse-á, agora, para o que disserta a Lei n. ${ }^{\circ} 8078$, de 1,1 de setembro de 1990 , justamente aquela que veio trazer ao ordenamento coletivo existente um novo ferramental em clefesa dos já falados interesses difusos e coletivos, cujos conceitos cuidar-se-á mais à frente.

Na Lei n. ${ }^{8} .078$, 11.set.90(Código de Proteção e Defesa do Consumidor): art. 84:

Art. 84. Na aça que tenha por objeto o cumprimento da obrigação de fazer ou näo fazer, o juiz concedera a tutela especifica da obrigaça ou determinará providencias que assegurem o resultado pratico equivalente ao do adimplimento. $\S 1^{\circ}$ A conversão da obrigaça em perdas e danos somente será admissivel se por 
elas optar o autor ou se impossivel a tutela especifica ou a obtenção do resultado prático correspondente.

$\S 2^{\circ} \mathrm{A}$ indenização por perdas e danos, se fará sem prejuizo da multalart. 28717 do $C P C$.

$\$ 3^{\circ}$ Sendo relevante of fundamento da demanda e havendo justificado receio de ineficácia do provimento final, é licito ao juiz conceder a tutela liminarmente ou após justifícação prévia, citado o réu.

$\S 4^{\circ}$ O juiz poderá, na hipótese do $\S 3^{\circ}$ ou na sentença, impor multa diâria ao réu, independeniemente de pedido do autor, se for suficiente ou compativel com a obrigação, fixando prazo razoável para o cumprimento do preceito.

\$ $5^{\circ}$ Para a (efetivacáa da) tutela especifica ou para a obtenção do resultado prático equivalente, podera o juiz, (de oficio ou a requerimento) determinar as medidas necessärias, lais como@ busca e apreensäo, remogão de (pessoas e coisas) coisas e pessods, desfazimento de obra(obras), impedimento de atividade nociva, além de requisiçăo(forca) policial18.

Se, com a Lei n. 7.347 , de 24 de jutho de 1985, o legitimado ativo para propositura de ação civil pública é o Ministério Público, até por ser de sua funçäo institucional, conforme determina a Carta Magna, por outro lado com a advento da Lei n. 8.078 , de 11 de setembro de 1990 - Código de Proteçăo e Defesa do Consumidor -, houve um alargamento das pretensöes da sociedade para a defesa dos seus interesses, pois o art. $1^{\circ}$ da comentada lei diz, a toda a evidência, que

O presente Código estabelece normas de proteção e defesa do consumidor, (protecão) de ordem puiblica e (proteçao) de interesse social... - As expressóes "proteçāo" entre parênteses pertencem ao autor deste trabalho, como se vê, não são da lei.

O que se nota de pronto, desde o primeiro dos seus artigos, é que a

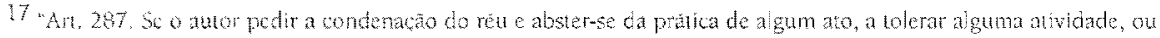

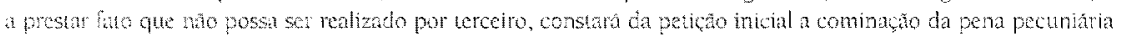
para o aro de descumprimento da senenga(aris. 64 \% e 645 )."

18 Na essuncia, cste parăgrafo tem a mesma diccão do $85^{\circ}$ do an 461 do Codigo de Processo Civil, a näo ser o que se enconta iqui cutre partentess, am negrito. 
intenção do legislador foi de estender o entendimento sobre os termos da aplicação deste Código, não só ao consumidor, embora este seja o seu nome, mas também à ordem püblica e, mais que isto, ao interesse social.

Neste diapasão, o citado Código, no dispositivo transcrito anteriomente(art. 84), cuidou igualmente da figura da antecipaçăo da tutela juxisdicional. Naturalmente que num entendimento exegético este artigo pode (e deve) ser aplicado em conjunto com outros dispositivos do ordenamento juridico, quando se tratar do necessário acautelamento em que não se deva prejudicar ofumus boni iuris e o periculum in mora, sejam estes demonstráveis na pretensão do interesse privado ou do interesse difuso ou do interesse coletivo. Se se fala nestes dois últimos, interesse difuso e interesse coletivo, é importante que se perscrutem os seus conceitos para, por lim, conhecer as variaveis que tratam do melo ambiente no âmbito da legislação pátria, buscando-se daí em diante enquadrar a tutela antecipatória no mandado de segurança, objetivo desta monografia. Encaminhe-se para lá, pois.

\section{DIREITOS DIFUSOS, COLETTVOS E INDIVIDUAL HOMOGENEO}

$T$ endo em vista o que até aqui se tem feito, isto é trazendo as figuras de importantes institutos do direito, tais como mandado de seguranca e a tutela antecipada para que se tenha, a final, uma verdadeira compreensão da matéria dissertada, resta, agora, conhecer, mesmo que forma rápida, os conceitos de direito diluso, coletivo e individual homogêneo, para, em seguida, discorrer sobre a legislação do meio ambiente e, finalmente, traçar linhas sobre a impetraça do mandado de segurança ambiental, com pedido de tutela antecipada.

Ada Pelegrini Grinover, na qualidade de Coordenadora da obra "A Tutela dos Interesses Difusos", nos idos de 1984, jả preconizava a A necessidade de soluça pacifica do conflito de interesses difusos, e sua tutela pelo ordenamento juridico, dizendo-os, desde então, que já eram indiscutiveis. 
E continuava:

Trata-se de interesses de massa, relativos à defesa do meio ambiente, à proteça de valores culurais e espirituais, à tutela do consumidor. E exatamente por sua configuraço coleiva e de massa, caracterizam-se por uma conflituosidade, também de massa, que não se coloca no clássico contraste individuo x autoridade, mas e que lipica das escolhas politicas. Quando a poluiçăo de um no afeta as populacoes ribeirinhas; quando laboratórios quimicos falsificam produtos farmacuticos; quando industrias alimenticias fraudam mithares de consumidores; quando complexos industriats poluem bairros e cidades; quando petroleiros provocam danos ecologicos ou predadores exterminam a fauna; quando a industria edilicia deteriora o patrimonio artístico, histórico ou turistico, verifica-se de mancira contundente e ate trágica a necessidade imperiosa e urgente de não deixar sem lutcla esses interesses comuns 19 .

Esta assertiva era a sinalização para a concretização dos direitos que transcencliam a ligura do indivíduo, alcançando a transidividualidade, em outras palavras, outorgando tais direitos a ninguém e a todos.

Destarte, o Cóligo de Proteção e Defesa do Consumidor(Lei n. ${ }^{\circ}$ 8.078, de l l de setembro de 1990), sets anos após a afimaçao da respeitável doutrinadora, trazia à luz os conceitos que eram perseguidos para tutelar os direitos coletivos e difusos, alem do chamado direito individual homogêneo, facilitando, por via de conseqüencia, o ingresso em Juízo para recompor prejuizos que extrapolassem a esfera do individuo isoladamente.

A conceituação de tais situações juridicas licou claramente definida no teor do diploma legal que passou a cuidar da proteção do consumidor, qual seja a Lei n. 8.078 , 11 de setembro de 1990, que trazia, com clareza, o entendimento de cada uma das situaçoes(interesses ou direitos difusos, interesses ou direitos coletivos $e$ interesses ou direitos individuais homogèneos).

Em tendo isto ocorrido, o ordenamento juridico brasileiro passava a contar com um importante arsenal para cuidar e tutelar os direitos 
transindividuais, isto é aqueles que ultrapassassem a órbita do indivíduo de forma isolada. Como se sabe, a nova legislação não ficava adstrita tão só à proteção do consumidor 20 , mas também poderia servir de apoio a outras incursões, como por exemplo a proteção e tutela do meio ambiente, para oncle se encaminha este trabalho.

Transcrevem-se os dispositivos do Código de Proteção e Defesa do Consumidor, para que os mesmos sejam conhecidos na sua integralidade; "Art. 81. A defesa dos interesses e direitos dos consumidores e das vitimas poderá ser exercida em juizo individualmente, ou a titulo coletivo:

Parágrafo unico. A defesa coletiva será exercida quando se tratar de:

I - interesse ou direitos difusos, assim entendido para efeitos deste Código, os transindividuais, de natureza indivisivel, de que sejam titulares pessoas indeterminadas e ligadas por circunstâncias de fato;

II - interesses ou direitos coletivos, assim entendidos, para efeitos deste Código, os transindividuais, de natureza indivisivel, de que seja titular grupo, categoria ou classe de pessoas ligadas entre si ou com a parte contrária por uma relacão juridica base;

III - interesses ou direitos individuais homogèneos, assim entendidos os decorrentes de origem comum.

Nesta rota já se tem por assentadas as linhas para buscar o ápice da presente monografia, a qual pretende apresentar uma análise do mandado de segurança para o resguardo dos bens ambientais, bastando, apenas, fincar o "bem da vida" que merecerá ser tutelado.

E este "bem da vida", a merecer tutela jurisdicional, será extraído do texto constitucional, que é o que se fará nas próximas linhas.

\section{DO MEIO AMBIENTE}

\section{1. - Na Constituição Federal/88: arts. 225 e 23, incisos VI e VII:}

$\mathrm{Na}$ parte final do item anterior, falou-se do "bem da vida" a ser tutelado pelo mandado de segurança ambiental. Evidentemente que o

20 NERY JR, Nelson, "in": Codigo de Processo Civil Comentado, 2. ed., Revista dos Tribunais, São Paulo, 8/1996, p. 1705: : "1:10. Direitos dilusos. Aplicaçāo do conceito legal. Por expressa determinação legal(CDC 90 LACP 21) as definiçôs legais de direitos difusos e coletivos(CDC 81 par. ün. I e II) sāo aplicâveis a todas as situaçóes em que é reclamado o cxame desses conceitos e não apenas às lides de consumo. (...)" - Destacou-se - 
mesmo deve ser procurado no interior do texto constitucional, pois é ali que se positivam os "direitos e garantias fundamentais" tanto aos brasileiros quanto aos estrangeiros residentes no País, a teor do Título II, onde repousa o art. $5^{\circ}$ do citado diploma fundamenta], que dentre outras tutelas garante, inclusive, e com ênfase, a inviolabilidade do direito à vida, e, garantida esta, garantida esta a higidez do homem e a sua própria saúde, pois, nunca é demais registrar, que um dos fundamentos nos quais se assenta a República Federativa do Brasil é a dignidade da pessoa humana(art. $1^{\circ}$, III, da CF/88).

Entretanto, não se há de quedar-se tão somente no referido Título II, quando se quer ver garantidos os direitos que a Carta Magna proporciona àqueles mesmos direitos que ela quer ver tutelados.

No que tange ao meio ambiente, não se pode perder de vista que os bens ali inseridos são de profunda importância à própria vida dos homens e a sua saúde. Celso Antonio Pacheco Fiorillo et allizl retratam com firmeza que além clas categorias de bens que o nosso ordenamento jurídico registra, quais sejam: público, privado e difuso; este último tem profunda relevância para a existência de todos.

Não foi por menos que a Constituição Federal dedicou algumas de suas passagens para reafirmar a importância do chamado bem difuso. Basta que se leia com atenção o que registra o art. 225 inserto no seu texto. É bom que se o laça, nesta oportunidade, para verificar a sua extensão para os atuais viventes deste País e para os seus pósteros.

Assim:

Art. 225, caput: Todos têm direito ao meio ambiente ecologicamente equilibrado, bem de uso comum do povo e essencial à sadia qualidade de vida, impondo-se ao Poder Público e à coletividade o dever de defendê-lo e preservá-lo para as presentes e futuras gerações.

Vê-se, à simples leitura, que o meio ambiente deve ser ecologicamente equilibrado, que se trata de uso comum do povo, isto é tem características e conformação de bem difuso, que não é de ninguém, porém é de todos. Não há, aqui, qualquer discriminação quanto ao seu uso e usufruto, pois os seus benefícios espraiam-se por lodo o território estejam onde estiverem os 
individuos que são alcançados pela tutela da referida norma constitucional.

A este propósito, nota-se que há perfeita sintonia entre o dispositivo citado e outro que se encontra no frontispício do Título II, onde todos são iguais perante a lei, sem distinçäo de qualquer natureza. E vai além, como já registrado na introdução deste trabalho, quando demonstrado ficou que, por força do art. 182 da mesma Carta Magna,

a politica de desenvolvimento urbano tem por objetivo ordenar o pleno desenvolvimento das funçoes sociais da cidade e garantir o bem-estar de seus habitantes.

Isto se vê reforçado quando se sabe que o homem tem o direito de morar(bem), circular(bem), trabalhar(bem) e divertir-se(bem), tal como preconizado pela Carta de Atenas, documento vindo à luz no longínquo ano de 1934 por inspiração de Le Corbusier, afamado arquiteto deste século.

Ora, se se deve tratar o meio ambiente, natural ou artificial, como bem difuso, interesse de todos, "bem da vida", enfim, não se pode deixar de preservá-lo na sua plenitude, razão por que o Direito deve oferecer as ferramentas para o exercicio da sua tutela.

Neste raciocínio, há de se lembrar que a Constituição Federal quando fala da imposição ao Poder Público de preservar o meio ambiente, registra, na competência comum dos entes federados, o dever que todos têm em proteger o meio ambiente e combater a poluição em qualquer de suas formas, por lorca do seu art. 23, VI, bem como determina preservar as florestas, a fauna e a flora, agora na prescricão do inciso VII do mesmo artigo.

Observa-se, em conseqüencia, embora seja uma competência comum entre a União, os Estados, os Municipios e o Distrito Federal, que é mais do que isto, havendo na norma constitucional um verdadeiro mandamento para a tutela e o resguardo desse bem cujo conteúdo é de uma importante transindividualidade

Nesta óptica, não pode o Poder Público furtar-se em cumprir a sua tarefa preservacionista, posto que, em isto não ocorrendo, seria uma afronta ao prescrito no art. 225 - impondo-se ao Poder Público (...) o dever de 
defendê-lo e preservá-lo para as presentes e futuras gerações. - Não se perca de vista, por igual, que tal comando dirige-se também à coletividade impondo-se (...) a coletividade o dever de defendê-lo e preservá-lo para as presentes e futuras gerações. -. Em outras palavras, o dever de preservação é a um só tempo tanto do Poder Público quanto da coletividade ${ }^{22}$.

Contudo, as prescriçóes aqui trazidas não estão só no texto constitucional, pois a legislaçāo infraconstitucional cuida de mostrar a sua forma de operacionalização, que é o que se verá adiante.

\section{2. - Na Lei n. ${ }^{\circ}$ 6.938, 31.ago.81}

\section{(Politica Nacional do Meio Ambiente):}

A legislação infraconstitucional, representada pela Lei Federal n. ${ }^{0}$ 6.938 , de 31 de agosto de 1981 , busca regulamentar as disposições da Constituiçáo Federal - arts. 23, VI e VII, e 225, estabelecendo, por consequéencia, o que se denominou de Politica Nacional do Meio Ambiente, visa a preservação, melhoria e recuperação da qualidade ambiental propicia à vida, visando assegurar, no País, condições ao desenvolvimento sócio-econômico, aos interesses da segurança nacional e à proteção da dignidade da vida humana, consoante o registro do seu art, $2^{\circ}$.

Além disto, ela registra uma série de princípios que vêm elencados nos incisos de I a X. Todos eles se completam numa verdadeira tessitura que busca atender ao "bem da vida" de que se falou linhas atrás.

Assim está grafada:

Art. $1^{\circ}$ - Esta Lei, com fundamento nos incisos VI e VII do art. 23 e no art. 225 da Constituição, estabelece a Politica Nacional do Meio Ambiente, seus fins e mecanismos de formulaçăo e aplicação, constitui o Sistema Nacional do Meio Ambienle - SISNAMA e institui o Cadastro de Defesa Ambiental.

DA POIITICA NACIONAL DO MEIO AMBIENTE

Art. $2^{\circ}$ - A Politica Nacional do Meio Ambiente tem por objetivo a preservação,

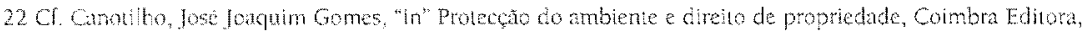
Comba, $3995, p, 48$. O consintucionatmente consagrado dircito ao ambiente sempre havert de ser anatisado na vertente do etulibro ecologico de imediato efeito para a vida humana. 
melhoria e recuperaçäo da qualidade ambiental propicia à vida, visando assegurar, no Pats, condiçoes ao desenvolvimento sócio-economico, aos interesses da segurança nacional e à proteção da dignidade da vida humana, atendidos os seguintes principios:

I. - açäo governamental na manutenção do equilibrio ecológico, considerando o meio ambiente como um patrimônio público a ser necessariamente assegurado e protegido, tendo em vista o uso coletivo;

II - racionalizaça do uso do solo, do stibsolo, da água e do ar;

III - planejamento e fiscalização do uso de recursos ambientais;

IV - proteção dos ecossistemas, com a preservação de áreas representativas;

$V$-controle e zoneamento das atividades potencial ou efetivamente poluidoras;

VI - incentivos ca estudo è pesquisa de tecnologias orientadas para o uso nacional e a proteção dos recursos ambientais;

VII - acompanhamento do estado da qualidade ambiental;

VIII - recuperaça de áreas degradadas;

IX - proteçóo de areas ameaçadas de degradação;

$X$ - educaça ambiental a todos os niveis de ensino, inclusive a educaçäo da comunidade, objetivando capacitála para participacăo ativa na defesa do meio combiente."

Neste passo, verifica-se que a Politica Nacional do Meio Ambiente, da Corma como está estruturada nesta Lei, elege como principios os incisos que decorrem do seu art. $2^{\circ}$, através dos quais busca objetivar

a preservaço, methoria e recuperacão da qualidade ambiental propicia à vida, visando assegurar, no Pais, condiçôes ao desenvolvimento sócio-económico, aos interesses da seguranca nacional e à protecão da dignidade da vida humana. Destacou-se - .

Esta marca na Lei, demonstra o cuidado do legislador ordinärio em transferir do Texto Magno para ela, para que cumpram efeitos positivos23,

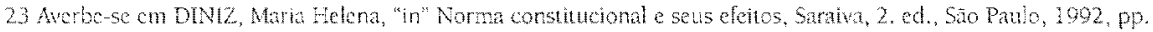

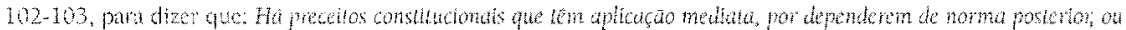

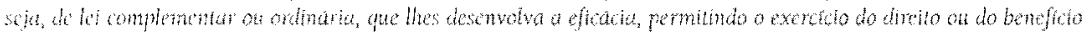

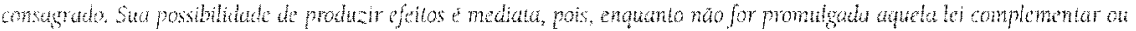

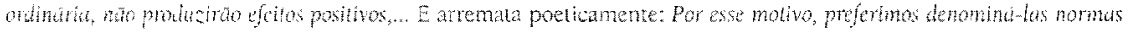

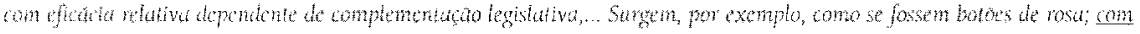

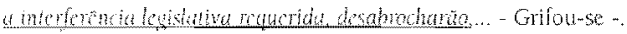


princípios e fundamentos, que estão inseridos em todo o sistema constitucional.

No que aqui interessa, registre-se, por exemplo, o disposto no art. 225, da Lei Federal n. 6.938 , de 31 de agosto de 1981, quando prescreve afirmativamente que TODOS $^{24}$ (Ou serão somente os brasileiros $e$ estrangeiros residentes no País?) têm direito ao meio ambiente ecologicamente equilibrado, direito que, desrespeitado, seja por ilegalidade ou abuso de poder por parte de autoridade pública ou agente de pessoa juridica no exercicio de atribuiçóes do Poder Público (CF/88, art. 5\%, LXIX, parte final, - destacou-se -), para ser restabelecido, a teor da dicção constitucional(art. 5\%, XXXV: a lei não excluirá da apreciação do Poder Judiciário lesão ou ameaça de direito), poderá ser objeto de mandado de segurança(CF/88, art. 5\%, LXIX e LXX), que é o objetivo deste trabalho e do qual dissertaì-se-á no próximo tópico.

\section{CONSIDERAÇÕES FINAIS}

Vencidos os caminhos anteriores, chega-se, agora, ao estágio final do trabalho, quando tratar-se-á da aplicabilidade do mandado de segurança como tutela jurisdicional(e antecipaçăo dela) em direito ambiental.

Desnecessário será frisar que o mandado de segurança, nos termos da norma constitucional, existe (e concede-se-o)

para proteger direito liquido e certo, (...), quando o responsável pela ilegalidade ou abuso de poder for autoridade publica ou agente de pessoa juridica no exercicio de atribuicóses do Poder Público.

A própria Carta Constitucional começa por dar noticia de quem são os

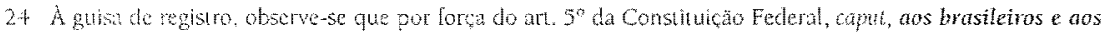
estrangefros wsidentes no pars gantem-se alguns direitos, como, por exemplo a inviolabildade do diveilo it wida, o dieito a hierdade, o direito a igualdade, o diretio a seguranca, o direto a propriedade. Enquanto que, na

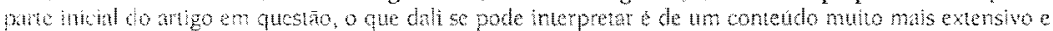

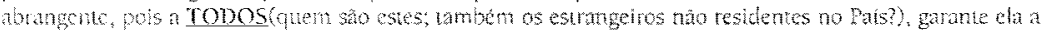

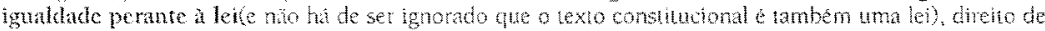
concudo muto mais abrangente do que a simples emuncago de cenos direlos cono resa registrado na noma

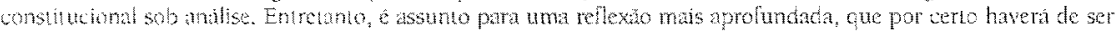
feiti: 
legitimados ativos para a impetração da ação sob exame. No inciso LXIX, aquele que possua capacidade processual para fazê-lo, tratando-se, como se pode notar, cle pessoa(física ou jurídica) individualmente; no inciso LXX, por se tratar da legitimação coletiva, os ali indicados: partido político com representação no Congresso Nacional; organização sindical, entidade de classe ou associação, em defesa dos interesses de seus membros ou associados, posto que aqui, no mandado de segurança coletivo, em não havendo, ainda, uma regulamentação a respeito, deverão ser obedecidos os limites das clecisões já prolatadas em nossos Tribunais superiores, quanto aos procedimentos processuais.

Outra característica, singularidade mesma do mandado de segurança, de que haja direito líquido e certo ferido 25 , ou na iminência de ser ferido, e que o seja por autoridade pública ou agente de pessoa jurídica no exercício de atribuições do Poder Público. Lembre-se, por importante, que direito líquido e certo é algo que deve ser provado de imediato, sem qualquer dilação probatória 26 , posto que, se assim fosse, dilatando-se os meios de prova, desnaturar-se-ia a essência deste direito constitucional.

Ao se penetrar neste ponto, o do direito líquido e certo, e dos meios de prová-lo, ab initio, isto é na abertura da demanda, começa para o impetrante de um possivel mandado de segurança de cunho ambiental um grande tormento.

E isto se explica.

Normalmente, quando são envolvidas questões ambientais para a consecução da prova há necessidade da participação de perito27 e com as variáveis que esta mesma participação permeia o Código de Processo Civil, como por exemplo: exames, vistorias, avaliações, participação de assistentes, contraclitório etc.

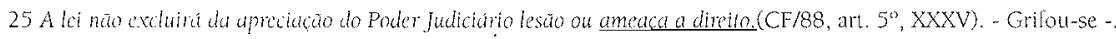

26 CI. PONTES DE MIRANDA, "in" Comentários a Constituiçăo de 1967 com a Emenda 1 de 1969, RT, Tomo V(ăts. 153, \$ 2"-159), São P'aulo, 1974, p. 360. Direito certo e líquido e aquêle que não desperta dívidas, que está isento de obséturidades, que nũo precisa ser aclarado com o exame de provas em dilaçoes, que é, de si mesmo, concludence inconcusso.

27 Codigo de Processo Civil, art. 145: Quando a prova do fato depender de conhecimento técnico ou cientílico, o juiz seri assistido por perito, segundo o disposto no arl. 421. (arl. 421: O juiz nomeara o perito, Íixando de imediato o prazo para in enurega do laudo.) 
Logo, e de pronto, há de afastar-se a hipótese de utilização do mandado de segurança para a tutela do meio ambiente ofendido, ação que só pode ocorrer na hipótese de proteçăo a direito líquido e certo, quando o responsável pela ilegalidade ou abuso de poder for autoridade ou agente de pessoa juridica no exercicio de atribuiçóes do Poder Público, nos precisos termos do art. $5^{\circ}$, LXIX, da CF/88, na sua parte final.

Num simples raciocínio, dependente de pericia, exame, vistoria ou avaliaçao, como quer o Código de Processo Civil, afastada está a viabilidade de impetração da comentada ação constitucional, pois não se caracteriza o dreito como líquido e certo, pois deixa de ser aquele direito que não desperta dúvidas, que não está isento de obscuridades, que (...) precisa ser aclarado com o exame de provas em dilações, que não $\dot{e}$, de si mesmo, concludente e inconcusso, justamente o contrário do que ensinou Pontes de Miranda, em referência anteriormente apontada(nota de rodapé $n{ }^{\circ} 25$ ), quando esclarecia o inteiro conteúdo do que seja direito liquido e certo.

Todavia, quando as provas são incontestes, quando há fato notório28, pode-se pensar, de forma aprioristica, estar o tormento sanado. Ledo engano, pois se, de um lado, pode ocorrer o fato notório, por outro prisma, nem sempre este consubstancia a verdadeira agressão ao meio ambiente, que é o objetivo de que aqui se trata, porque pode estar, ainda, dependente de mensuração quanto à extensão do problema, passivel de pericia, exame, vistoria, avaliaça etc...

Uma das posiçoes heróicas do mandado de segurança consubstanciase na concessão de medida liminar, existentes o fumus boni iuris e o periculum in mora, ou no ensinamento de Hely Lopes Meirelles:

A medida liminar e provimento cautelar admitido pela propria lei de mandado de seguranç, quando sejam relevantes os fundamentos da impetração e do ato impugnado puder resultar a ineficácia da ordem judicial, se concedida a final (art. 7"., II). Para a concessäo da liminar devem concorrer os dois requisitos legais, ou

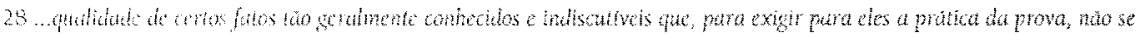

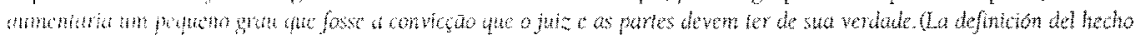

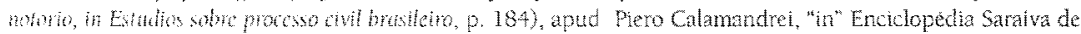

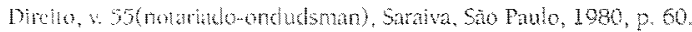


Seja, a revancia dos motivos em que se assenta o pedido na inicial $c$ a possibilidade da ocomencia de lesao inteparavel ao diretio do impetrante, se vier a sel ranhecido na decisáo de mérito. A medida liminar nâo é concedida como antecipacto ${ }^{29}$ dos efeitos da sentenca final; e procedimento acautelador dos possivel diveito do impetrante, justificado pela iminencia de dano irreversivel de ordem patrimanial, funcional ou moral, se mantido o ato coator até a apreciacäo definitiva da causa. Por isso mesmo, não importa em prejulgamento; não afirma direitos; nem nega poderes a Administraçao. Preserva, apenas, o impetrante de lesco irreparavel, sustando provisoriamente os efeitos do ato impugnado 30.

Mesmo assim, só se pode receber a sua concessão, presentes ofumus boni iuris e periculum in mora, mas que o direito seja liquido e certo, o que nos casos envolvendo o meio ambiente, pelas razoes já invocadas, é trabatho para mouro.

Un ultimo passo nesta tarefa refere-se à figura do legitimado passivo.

Já lol dilo que o mandado de seguranca individual ou coletivo prestase para proteger direito liquido e certo, (...) quando o responsável pela ilegalidade ou abuso de poder for autoridade publica ou agente de pessoa juridica no exercício de atribuicöes do Poder Pública.

Isto está claro, pois é comando constítucional(art. $5^{\circ}, \mathrm{LXIX}$ ).

Logo se verilica que o legitimado para o pólo passivo de uma açáo de pedir mandado de segurança tem de estar servindo a Administraça Pública, no pleno exercicio de suas funçoes, na qualidade de agente público, em quaisquer de suas espécies, seja: agente politico, servidor públicolcivil, militar, governamental), agente temporário ou agente de colaboraça (por vontade própria, por compulsão, por concordancia), na útil classificação de Diogenes Gasparini3l.

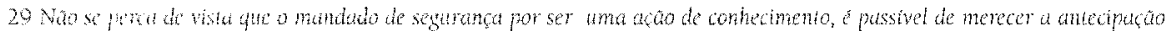

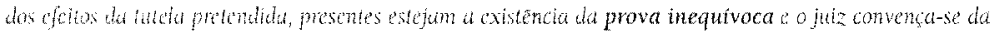

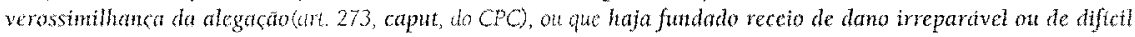

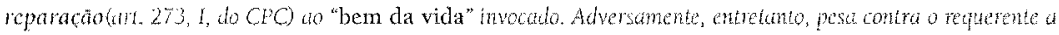

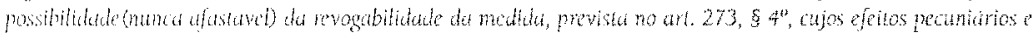

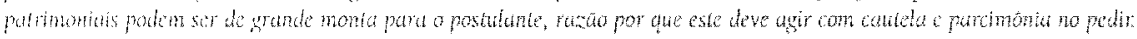
30 Op. cite 50.

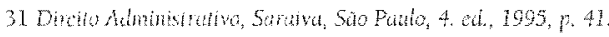


Registre-se, neste passo, os que se localizam noutro lado da relaçäo processual em ação de pedir mandado de segurança, e de forma mais detida no tocante ao remédio coletivo, novidade trazida pela atual Constituiçáo Federal, como já visto: a partido politico com representação no Congresso Nacional; organizaçăo sindical, entidade de classe ou associação, em defesa dos interesses de seus membros ou associados.

Sem qualquer dúvida, são estes que estão perfeitamente identificados com as causas da população e que podem advogar, sobretudo, os interesses de natureza difusa ou coletiva, onde localizam-se os que se voltam para a defesa do meio ambiente, pois é, todos o sabem, bem de valor geral da sociedade.

Como afirmam Fiorillo et alli, para delender a idéia de que os nominados na letra b, do inciso $L X X$, do art. $5^{\circ}$, da CF/88, näo estão ali tão só para a defesa do interesse dos seus membros ou associados, mas também para a defesa dos interesses difusos, pois escrevem:

Ora, não pairam dúvidas, e nem poderia, de que os direitos difusos podem e devem ser tutelados, pois, em tais associações, o caráter difuso do direito está intimamente relacionado com os interesses de seus membros e associados. Aliás, diga-se de passagem que até esvaziada ficaria a norma se nāo tomássemos este entendimento, já que, pelo entendimento do inciso III do art. $8^{\circ}$ (com relação aos sindicatos) e o inciso XXI do art. $5^{\circ}$ (com relação às associaçoes), já seria possivel a possibilidade de os sindicatos defenderem os direitos e interesses coletivos ou individuais da categoria, seja judicial ou extrajudicialmente 32 .

Feitas todas estas considerações, não há dúvida em afirmar, concluindo, que o mandado de segurança embora heróico remédio constitucional, mesmo com o acréscimo da legitimaçäo ativa trazida pelo atual Texto Constitucional, encontra óbices em seu caminho para que seja aplicado à tutela do meio ambiente, tais como a caracterização do direito liquido e certo, bem como da préconstituição da prova, além de que o poluidor ou agressor do meio ambiente, na maioria das vezes, não se corporifica na figura da autoridade pública ou agente de pessoa juridica no

320 ap ap $205-206$ 
exercicio de atribuiçóes do Poder Pública, mas também da coletividade, a quem incumbe também, juntamente com este, o dever de defender o meio ambiente de preservá-lo para as presentes e futuras geraçōes, nos exatos temos do att. 225 da Constituição Federal.

\section{RFFERENCIAS BIBLIOGRÁFICAS}

ATALBA, tieraldo Decadencia e Mandado de Segurançámenstitucionalidade do Proceito do Art. 18 da Lai 1.53375H. Revista Trimestral de Direito Poblico, V. 1/1993, p. 147.

BASTOS, Cols Ribim a MARTINS, Ives Gandm. Comentários à Constituiça do Brasil(Promulgada em 5 de ounbro de 1988), Samiva, $2^{\circ}$ bol (arts $5^{\circ}$ a 17 ), Säo Paulo, 1989 ;

BDINETET Luiz Fumanch. Mandado de Segurança Coletivo, Tese de Doutorado defendida junto a Pontifica Unirasidude Catolica de 5a Rmlo, 1997;

CANonth To, Jos Jaquim Gomes. Protecça do Ambiente e Direito de Propriedade(Critca de Jurispudencia Ambient), Combra Editora, Coimbra, 1995; Direito Constitucional Almedina, 6. ed., Coimbra, 1993;

CARNFIRO, Ruy de Jests Matchl A Constituçăo Federal de 1988 e a desapropriaça com efeitos urbanísticos,

Dissentacio de Mestrado defondich junto a Pontificia Universidade Cabolica de Sa Panlo, 1996;

DNAMARCo, Candido Rungel A Refortma do Código de Processo Civil, Malheiros, 3. ed, Sao Paulo, 1996;

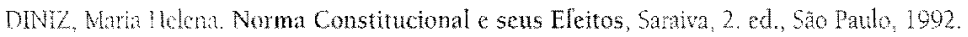

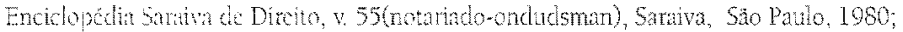

TERRAz, Strgn, Mandado de Seguança(Individual e Coletivo) Aspectos Polēmicos, Malheiros, 5ão Palo, 1992; FGUFIREDO J Góa Valle. Perfil do Mandado de Segurança Coletivo, RT. Säo Patio, 1989;

FlORLL1O, Celso Antonio Picheco, RODRGGUS, Marelo Abeha e NERY, Rosa Mara Andrade. Direito Processual

Ambiental Brasilciro, De Rey, Belo Llotizonte, 1996;

GRINOVER, Ach Pelegrinicoordancano). A Tutela dos Interesses Difusos - doutrina, jurisprudencia e trabahos

Forenses -, Max Limonad, Sio Pado, 1984;

MANCUSO, Rodulo de Cmmgo. Interesses Difusos - Conceito e legitimaça para agir, RT, 520 Faulo, 1988; MEREL ES, Iely Lopes. Mandado de Segurança, Acăo Popular, Ação Civil Publica, Mandado de Injuncão,

"Fubcas-Duta", RT, $12 \mathrm{~cd}$, Saro Pullo, 1989;

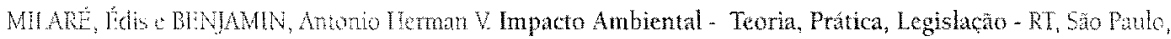
$190 \%$

NERY Junim, Nelson, Principios do Processo Civil na Constituicăo Federal, Coleçáo Estudos de Direto de

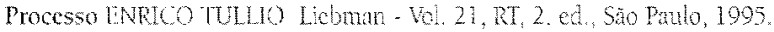

NERY Junim, Nelson e NERY, Rosa Maria Anthade. Código de Processo Civil Comentado, Editora Revista dos

Tribunim, 2. al, sio ramb, 1996:

OLIVLRA, Frenciso Antonio de. Mandado de Segurança Controle Jurisdicional, RT, 5ão Panlo, 1092;

PACHECO, lose da Silva O Mandado de Seguranęa e outras aços constitucionais típicas, RT, Să Paulo, 2 , cd. 1901

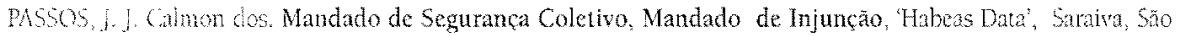
Piule, 1989

PONTES DE MLANDA, Comentánios a Constituicão de 1967 com a Emenda 1 de 1969, RT, Tomo Vhars. 153 ,

$\$ 2^{\prime \prime}-154$, sin Pituro, 1974;

SIVA, Jos Afonso. Dircito Ambiental Constitucional, Waheiros, Sa Palo, 1994;

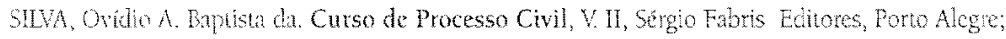

TEMHR, Michel. Elcmentos de Direito Constitucional, Matheiros, Săo Pato, 1992: 